\begin{tabular}{|c|c|c|}
\hline \multirow{2}{*}{ - } & $\begin{array}{l}\text { International Journal of Current Research in } \\
\text { Biosciences and Plant Biology }\end{array}$ & $=$ \\
\hline & Volume 6 • Number 5 (May-2019) • ISSN: 2349-8080 (Online) & \\
\hline $\begin{array}{l}\text { EXCELLENT } \\
\text { PUBLISHERS }\end{array}$ & Journal homepage: $\underline{w w w . i j c r b p . c o m}$ & \\
\hline
\end{tabular}

\title{
Phytochemical, antibacterial, antioxidant and cytotoxic activities of methanol and aqueous leaf extracts of Pyrrosia heterophylla (L.) M.G. Price
}

\author{
Mini Gopinathan, S. Manju and R. Pratap Chandran*
}

Department of Biotechnology and Research, K.V.M. College of Science and Technology, Kokkothamangalam P.O., Cherthala, Alappuzha District, Kerala State - 688527, India

*Corresponding author; e-mail: drpratapchandran@yahoo.co.in

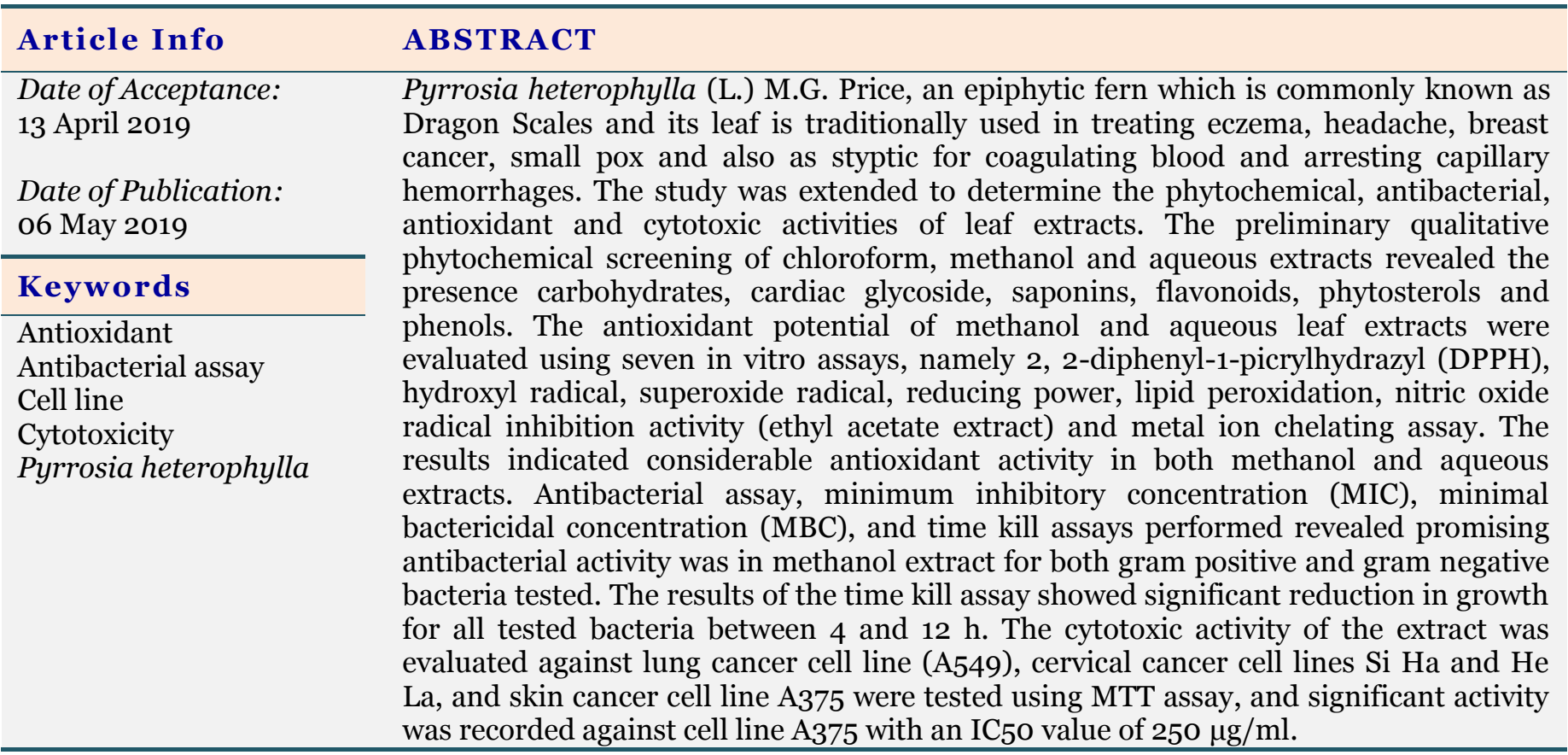

\section{Introduction}

Oxidative stress has been associated with the progression of chronic conditions such as acquired immune deficiency syndrome (AIDS), cancer, aging, atherosclerosis, inflammation, cardiovascular disease, diabetes and neurodegenerative diseases such as Parkinson's and Alzheimer's disease (Orhan, 2009). Natural compounds which are present in herbal products, vegetables, fruits and grains possess the ability to reduce oxidative damage by acting as antioxidants (Siddhuraju and Becker, 2007). Many antioxidants are plant-based and play an important role in protecting plants that are exposed to strong sunlight and live under severe oxygen stress. Thus 
interest in natural antioxidant, especially of plant origin has greatly increased nowadays (Jayaprakash and Rao, 2007).

Phytochemicals are often referred to as "secondary metabolites" of which there are several classes including alkaloids, flavonoids, coumarins, glycosides, gums, polysaccharides, phenols, tannins, terpenes and terpenoids (Harborne, 1973; Okwu, 2004). The active components are found in different parts and organs of plants, and they change or modify the functions of human and animal organs and systems. The phytochemical substances serve as molecules of plant defense against predation by microorganisms, insects and herbivores. They at the same time also exhibit medicinal properties for treating several ailments (Mithraja et al., 2012). Bacterial and fungal infection has been a major problem considered for decades that causes spoilage of food products and various diseases in plants, insects, and humans which leads to significant losses in the crop productivity and health problems across the globe (Gupta et al., 2011). In recent years, plant secondary metabolites (phytochemicals), previously with unknown pharmacological activities, have been extensively investigated as a source of medicinal agents (Krishnaraju et al., 2005). Thus, it is anticipated that phytochemicals with adequate antibacterial efficacy will be used for the treatment of bacterial infections (Balandrin et al., 1985).

Cancer is the abnormal growth of cells in our body and that can lead to death. Cancer cells usually invade and destroy normal cells. These cells are born due to imbalance in the body and by correcting this imbalance, the cancer may be treated. According to the American Cancer Society, deaths arising from cancer constitute $2-3 \%$ of the annual deaths recorded worldwide. Thus cancer kills about 3500 million people annually all over the world (Kathiresan et al., 2006). An integrated part of cancer cell development is the resistance to programmed cell death (apoptosis) and reestablishment of apoptosis in cancer cells is a target mechanism for anticancer agents (Joshi et al., 1999). Some plant derived products are known to selectively induce apoptosis in cancer cells, which represent the ideal property for successful anticancer agents (Hirano et al., 1995). Due to their multiple intervention strategies, crude plant extracts have been proposed to prevent arrest or reverse the cellular and molecular processes of carcinogenesis (Neergheen et al., 2009).

Investigation of the cellular growth control mechanisms has contributed to the understanding of carcinogenesis and identification of compounds with specific antitumoral activities. Thus, cytotoxicity screening models provide important preliminary data to help select plant extracts with potential antitumoral properties for future studies (Cardellina et al., 1999). Now a days, there is wide spread interest of drugs derived from plants which reflect its recognition of the validity of many traditional claims regarding the value of natural products in health care (Aggarwal and Shishodia, 2004). There are a few reports on the use of plants in traditional healing by either tribal people or indigenous community (Sandhy 2006; Ayyanar and Ignacimuthu, 2005; Rajan et al., 2002; Natarajan et al., 1999). P. heterophylla (Polypodiaceae) is an epiphyte found in many parts of Kerala, India and the leaves of the plant was traditionally used for treating swellings, cuts, wounds and fever. The present study was aimed to study the phytochemicals present in $P$. heterophylla and to evaluate the antibacterial, antioxidant and cytotoxic activities of leaf extracts.

\section{Materials and methods}

\section{Plant material and identification}

The plant P.heterophylla was collected from K.V.M. College of Engineering and IT campus, Cherthala, Kerala, India and authenticated as P. heterophylla by Dr. S. Abdul Kader, Assistant Professor, Department of Plant Biology and Plant Biotechnology, Presidency College, Chennai, Tamil Nadu, India and voucher specimens of the samples were stored at Presidency College, Chennai. The leaves of $P$. heterophylla were shade dried for one month. The dried leaves were then powdered and kept in an air tight container for further studies.

\section{Chemicals and media}

Mueller Hinton agar, nutrient agar, Czapek dox agar, Potato Dextrose agar (PDA), yeast extract, methanol, dimethylsulphoxide, Nitroblue tetrazolium (NBT), riboflavin, 2.2 Diphenyl -1picryl hydrazyl (DPPH), deoxyribose, quercetin, 
butylated hydroxyl anisol (BHA), ferrozine, potassium ferricyanide and the solvents used for extraction of active compounds (hexane, chloroform, dichloromethane, ethyl acetate, acetone, methanol) were purchased from HiMedia Laboratories Pvt. Limited, Mumbai, India. Trichloroacetic acid (TCA), Ethylene Diamine Tetra Acetic acid (EDTA) and ascorbic acid were purchased from Sisco Research Laboratories, Mumbai, India. Thiobarbituric acid (TBA) was purchased from Rolex Chemical Industries, Mumbai, India. All the chemicals and reagents used were of analytical grade and prepared in deionized water.

\section{Fluorescence analysis}

A small quantity of leaf powder was taken and two to three drops of different organic solvents like methanol, acetic acid, petroleum ether, water, $1 \mathrm{~N}$ $\mathrm{NaOH}, 50 \% \mathrm{HNO}_{3}, 1 \mathrm{~N} \mathrm{HCl}, 5 \% \mathrm{FeCl}_{3}, 1 \mathrm{~N} \mathrm{NaOH}$ in water, chloroform, acetone, $5 \% \mathrm{H}_{2} \mathrm{SO}_{4}$ and $5 \%$ $\mathrm{KOH}$ were added separately and mixed well. The slides were studied under short UV (280 to 100 $\mathrm{nm}$ ), long UV ( 400 to $315 \mathrm{~nm}$ ), and visible (390 to $700 \mathrm{~nm}$ ) light (Kokoshi, 1958).

\section{Phytochemical analysis}

Analysis of the plant for various phytochemical constituents present was carried out using standard methods (Sofowara, 1993; Trease and Evans 1989; Harborne 1973).

\section{Determination of total phenolic content}

The phenolic contents of methanol and aqueous extracts were determined according to Malik and Singh, 1980. Aliquots of the extracts were made up to $3 \mathrm{ml}$ with distilled water. Then $0.5 \mathrm{ml}$ folin ciocalteau reagent (1:1 with water) and $2 \mathrm{ml}$ $\mathrm{Na}_{2} \mathrm{CO}_{3}(20 \%)$ were added sequentially. The tubes with solution were warmed for 1 minute, cooled and the absorbance was measured at $760 \mathrm{~nm}$. The concentration of phenol in the test samples was calculated from the calibration plot and expressed as $\mathrm{mg}$ catechol equivalent of phenol/g of sample.

\section{Determination of flavonoid content}

Total flavonoid content of methanol and aqueous extracts were determined by aluminium chloride method (Chang et al., 2002). $1 \mathrm{ml}$ sample and $4 \mathrm{ml}$ of water were added to a volumetric flask. $0.3 \mathrm{ml}$ of $5 \%$ sodium nitrite and $0.3 \mathrm{ml}$ of $10 \%$ aluminium chloride were added after $5 \mathrm{~min}$ and kept for $6 \mathrm{~min}$ incubation at room temperature. To this, $2 \mathrm{ml}$ of 1 M Sodium hydroxide was added to the reaction mixture and immediately made up to $10 \mathrm{ml}$ with distilled water. The absorbance was read at $510 \mathrm{~nm}$ and the results were expressed as catechin equivalents (mg catechin/g dried extract).

\section{Percentage extractive of plant extracts}

Thirty grams of leaf powder was subjected cold extraction using each solvent $(250 \mathrm{ml})$ in the increasing order of polarity (hexane, chloroform, dichloromethane, ethyl acetate, acetone, methanol and water). The final filtrate of each of the extract was concentrated using a rotary vacuum evaporator (IKA RV-10 Digital, Germany) were collected, evaporated to dryness and stored at $4^{\circ} \mathrm{C}$ for further studies. The percent extractives of cold extracts of all the seven solvents were calculated by using the formula

$$
\text { Percentextractive }=\frac{\text { Weight of dried extract }}{\text { Weight of dried plant material }} \times 100
$$

\section{Pathogenic microbial strains}

Five gram negative (Escherichia coli (MTCC 729), Klebsiella pneumoniae (MTCC 432), Proteus mirabilis (MTCC 425), Pseudomonas aeruginosa (MTCC 4676) and Salmonella typhi (MTCC 3216) and three are gram positive, Bacillus subtilis (MTCC 619), Bacillus cereus (MTCC 430) and Staphylococcus epidermidis (MTCC 3615) bacterial strains were used. All these pathogenic strains were procured from the Microbial Type Culture Collection and Gene Bank (MTCC), Chandigarh, India. These bacterial strains were sub cultured frequently in suitable agar slants and stored at $4^{\circ} \mathrm{C}$ for further studies.

\section{Antibacterial assay}

Antibacterial assay was carried out by disc diffusion method (Bauer et al., 1966). Different solvent extracts of the plant were tested against the selected bacterial strains mentioned above. The test bacterial cultures were evenly spread over Mueller Hinton agar plates using a sterile cotton 
swab. The sterile discs (6 $\mathrm{mm}$ in diameter) were impregnated with extract solution and placed in the inoculated agar. All plates were then incubated at $37^{\circ} \mathrm{C}$ for 24 hours and the zone of inhibition were subsequently measured in $\mathrm{mm}$. Ciprofloxacin $(5 \mu \mathrm{g} / \mathrm{ml})$ was used as a positive control and respective solvents serve as a negative control. The experiment was done in triplicates and the mean values were presented.

\section{Minimum inhibitory concentration}

The minimum inhibitory concentration (MIC) was determined according to the method described by Clinical and Laboratory Standards Institute (CLSI, 2012), with some modification. Two fold serial dilutions of the antibiotic and extract were made with Mueller Hinton broth (MHB) to give concentrations ranging from 2 to $4000 \mu \mathrm{g} / \mathrm{ml}$. Hundred microliters of test bacterial suspension were inoculated in each well to give a final concentration of $1 \times 10^{5} \mathrm{CFU} / \mathrm{ml}$.

The tubes were incubated for $24 \mathrm{~h}$ at $37^{\circ} \mathrm{C}$. The control tube did not have any antibiotics or test compounds, but contained the test bacteria and the solvent used to dissolve the antibiotics and compounds. The growth was observed both visually and by measuring $\mathrm{OD}$ at $600 \mathrm{~nm}$. The lowest concentration of the test sample showing no visible growth was recorded as the MIC. Triplicate sets of tubes were maintained for each concentration of the test sample. Ciprofloxacin was used as a positive control.

\section{Time kill assay}

The potential of compound carryover during the plating process were determined by following CLSI method (2012). The dilutions yielded a starting inoculum of approximately $1 \times 10^{6} \mathrm{CFU} / \mathrm{ml}$. The test bacteria were exposed over time to extract and antibiotics. Tests were performed at $0,2,4,6,12$ \& $24 \mathrm{~h} .100 \mu \mathrm{L}$ samples were removed from each test suspension, serially diluted in sterile saline and plated on nutrient agar plates for colony count determination. Plates were incubated at $37^{\circ} \mathrm{C}$ for $24 \mathrm{~h}$. The broth without any agent was used as the control for bacterial growth at each time point. The data were plotted as $\log \mathrm{CFU} / \mathrm{ml}$ versus time (h) for each time point. Tests were performed three times.

\section{Antioxidant assays}

\section{Reducing power assay}

Ferric reducing power of extracts was determined following method described by Oyaizu, 1986. One $\mathrm{ml}$ of extract at various concentrations 25 $2000 \mu \mathrm{g} / \mathrm{ml}$ was respectively added to phosphate buffer $(2.5 \mathrm{ml}, 0.2 \mathrm{M}, \mathrm{pH}$ 6.6) and potassium ferricyanide $(2.5 \mathrm{ml}, 1 \%)$ followed by mixing and incubated at $50^{\circ} \mathrm{C}$ for $20 \mathrm{~min}$. Then, TCA $(2.5 \mathrm{ml}$, $10 \%)$ was added to the mixture and centrifuged at $3000 \mathrm{rpm}$ for $10 \mathrm{~min}$. $2.5 \mathrm{ml}$ of the supernatant was taken out and mixed with $2.5 \mathrm{ml}$ of distilled water followed by the addition of ferric chloride (0.5 ml, 0.1\%) and vortexed. Absorbance of the mixtures was read at $700 \mathrm{~nm}$ by using spectrophotometer. All the values were taken in triplicate and the ability to chelate ferrous ion was calculated using the formula given below:

$$
\text { Percetage of inhibition }=\frac{O D \text { of control }-O D \text { of test }}{\text { OD of control }} \times 100
$$

\section{DPPH radical scavenging activity}

The electron donation ability of the plant extracts was measured from bleaching of the purple colour of 2.2 Diphenyl -1-picryl hydrazyl (DPPH) (Coruh et al., 2007). $0.1 \mathrm{ml}$ of extract with varying concentrations $(25-2000 \mu \mathrm{g} / \mathrm{ml})$ was added to 1.4 $\mathrm{ml}$ of DPPH solution. The mixture was properly shaken and incubated at ambient temperature in dark for $30 \mathrm{~min}$ and the absorbance at $517 \mathrm{~nm}$ was recorded. The capability to scavenge the DPPH radical was calculated using the following equation

$$
\text { Percetage of inhibition }=\frac{\text { OD of control }- \text { OD of test }}{\text { OD of control }} \times 100
$$

\section{Superoxide radical scavenging activity}

Scavenging activity of aqueous and methanol extracts on superoxide anion radicals was spectrophotometrically determined based on the reduction of Nitroblue tetrazolium (NBT) which depends on light induced superoxide generation by riboflavin (McCord and Fridovich 1969). Different concentrations $(25-2000 \mu \mathrm{g} / \mathrm{ml})$ of $P$. heterophylla extract were added to the reaction mixture containing EDTA, o.1M containing $1.5 \mathrm{mg}$ sodium cyanide $(\mathrm{NaCN})$, riboflavin $(0.12 \mathrm{mM})$, 
NBT $50 \mu \mathrm{M}$, and phosphate buffer $(67 \mathrm{mM}, \mathrm{pH}$ 6.8 ) in a final volume of $3 \mathrm{ml}$. The tubes containing the reaction mixture were continuously illuminated with incandescent lamp for 15 minutes. The optical density was read at $530 \mathrm{~nm}$ before and after illumination against phosphate buffer as blank. The effect of test material to inhibit super oxide generation was evaluated by comparing the OD of control and treated tubes and the percentage of inhibition was calculated using the equation

$$
\text { Percetage of inhibition }=\frac{O D \text { of control }-O D \text { of test }}{O D \text { of control }} \times 100
$$

\section{Hydroxyl radical scavenging activity}

Hydroxyl radical scavenging activity of extract was measured according to the method described by Halliwell, 1994. One $\mathrm{ml}$ of the final reaction mixture consisted of aliquots $(500 \mu \mathrm{l})$ of various concentrations of the extract, $1 \mathrm{mM} \mathrm{FeCl}, 1 \mathrm{mM}$ EDTA, $20 \mathrm{mM} \mathrm{H}_{2} \mathrm{O}_{2}, 1 \mathrm{mM}$ L-ascorbic acid, and 30 $\mathrm{mM}$ deoxyribose in potassium phosphate buffer ( $\mathrm{pH}$ 7.4). The reaction mixture was incubated for 1 $\mathrm{h}$ at $37^{\circ} \mathrm{C}$, and further heated in a boiling water bath for $15 \mathrm{~min}$ after the addition of $1 \mathrm{ml}$ of $2.8 \%$ (w/v) trichloroacetic acid (TCA), and $1 \mathrm{ml}$ of $1 \%$ (w/w) 2- thiobarbituric acid. After cooling, the absorbance was measured at $532 \mathrm{~nm}$ against phosphate buffer blank. Hydroxyl radical scavenging activity was expressed as the percentage of inhibition of 2-deoxyribose oxidation by hydroxyl radicals and was calculated according to the equation

$$
\text { Percetage of inhibition }=\frac{\text { OD of control }- \text { OD of test }}{\text { OD of control }} \times 100
$$

\section{Metal ion-chelating assay}

The ferrous ion chelating potential of the extract at different concentrations was determined according to Gulcin, 2006. Different concentrations of the sample $(25-2000 \mu \mathrm{g} / \mathrm{ml})$ were added to a solution of $2 \mathrm{mM}$ iron (II) chloride (0.05 ml). The reaction was initiated by the addition of $5 \mathrm{mM}$ ferrozine $(0.2 \mathrm{ml})$ and the volume of the mixture was finally adjusted to $4 \mathrm{ml}$ with ethanol, shaken vigorously and left standing at room temperature for $10 \mathrm{~min}$. After the mixture had reached equilibrium, the chelating activity of the solution was measured spectrophotometrically at $562 \mathrm{~nm}$. The ability to chelate ferrous ion was calculated using the equation

$$
\text { Percetage of inhibition }=\frac{O D \text { of control }-O D \text { of test }}{\text { OD of control }} \times 100
$$

\section{Lipid peroxidation assay}

Anti-lipid peroxidation assay was performed with goat liver homogenate as per the protocol of Mandal et al., 2009. $2.8 \mathrm{ml}$ of $10 \%$ goat liver homogenate, $0.1 \mathrm{ml}$ of $50 \mathrm{mM}$ ferrous sulphate and $0.1 \mathrm{ml}$ of test sample $25-2000 \mu \mathrm{g} / \mathrm{ml}$ were added and the reaction mixture was incubated at $37^{\circ} \mathrm{C}$ for $30 \mathrm{~min}$. The reaction was terminated by adding 2 $\mathrm{ml}$ of $10 \%$ TCA and $0.67 \%$ TBA made in 50\% acetic acid and boiled for 1 hour at $100^{\circ} \mathrm{C}$, followed by centrifugation for $5 \mathrm{~min}$ at $10,000 \mathrm{rpm}$ and supernatant was read at $535 \mathrm{~nm}$ against blank. The reaction mixture without test sample and $\mathrm{FeSO}_{4}$ is used as control.

\section{Nitric oxide radical inhibition activity}

Ethyl acetate extract was used for the analysis of nitric oxide radical inhibition activity. Sodium nitroprusside in an aqueous solution at physiological $\mathrm{pH}$ spontaneously generates nitric oxide and interacts with oxygen to produce nitrite ions, which can be estimated by the use of GriessIllosvoy reaction (Kumar et al., 2014).

In the present investigation, GriessIllosvoy reagent was modified using naphthylethylenediamine dihydrochloride (0.1 \% w/v) instead of 1naphthylamine (5\%). The reaction mixture $(3 \mathrm{ml})$ containing sodium nitroprusside (10 mM, $2 \mathrm{ml}$ ), phosphate buffer saline $(0.5 \mathrm{ml})$, and different concentrations of ethyl acetate extract $\left(25^{-250}\right.$ $\mu \mathrm{g} / \mathrm{ml})$ or standard solution $(0.5 \mathrm{ml})$ was incubated at $25^{\circ} \mathrm{C}$ for $150 \mathrm{~min}$. After incubation, $0.5 \mathrm{ml}$ of the reaction mixture containing nitrite was pipetted and mixed with $1 \mathrm{ml}$ of sulphanilic acid reagent ( 0.33 in $20 \%$ glacial acetic acid) and allowed to stand for $5 \mathrm{~min}$ for completing diazotization. Then, $1 \mathrm{ml}$ of naphthyl ethylenediamine dihydrochloride (1\%) was added, mixed, and allowed to stand for 30 min. A pinkcolored chromophore was formed in diffused light. The absorbance of these solutions was measured at $540 \mathrm{~nm}$. BHA was used as positive control. 


\section{Cytotoxic activity}

\section{Preparation of $P$. heterophylla leaf extract}

About $50 \mathrm{~g}$ of dried, powdered P. heterophylla leaf were taken in an amber colored extraction bottle (500 ml capacity) and they were soaked with hexane, ethyl acetate and methanol $(500 \times 3$ times), respectively. The sealed bottle was kept for 7 days with occasional shaking and stirring. The combined extracts were filtered through cotton and then Whatman No.1 filter papers and were concentrated with a rotary evaporator under reduced pressure at $45^{\circ} \mathrm{C}$ to afford $0.102,0.118$ and $0.234 \mathrm{~g}$ of hexane, ethyl acetate and methanol crude extract. The extracts were filter sterilized using Millipore $0.22 \mu \mathrm{m}$ filter and stored at $4^{\circ} \mathrm{C}$ for further studies.

\section{Cancer cell lines tested, source and maintenance}

The following cell lines were used in the study. Lung cancer cell line (A549), cervical cancer ( $\mathrm{SiHa}$ and HeLa), skin cancer (A375) were purchased from National Centre for Cell Science, Pune, India and maintained in Dulbecco's Modified Eagle Medium (DMEM) supplemented with $10 \%$ FBS with antibiotics and antimycotics at $37^{\circ} \mathrm{C}$ in a $\mathrm{CO}_{2}$ incubator.

\section{Treatment of cell lines}

Stock solutions (100 $\mathrm{mg} / \mathrm{ml}$ ) of test samples, made in dimethyl sulfoxide (DMSO), were dissolved in corresponding medium to the required working concentrations. Lung cancer cell line (A549), cervical cancer ( $\mathrm{SiHa}$ and HeLa), skin cancer (A375) cell lines were seeded into 96-well microtiter plates, and $24 \mathrm{~h}$ later, after the cell adherence, five different, double diluted, concentrations of investigated compounds, were added to the wells. Final concentrations applied to target cells were 500, 250, 100, 50, 25 and 10 $\mu \mathrm{g} / \mathrm{ml}$, except to the control wells, where only nutrient medium was added to the cells. Nutrient medium was RPMI 1640 medium, supplemented with l-glutamine (3 mM), streptomycin (100 $\mu \mathrm{g} / \mathrm{ml}$ ), and penicillin (100 IU $/ \mathrm{ml}$ ), $10 \%$ heat inactivated $\left(56^{\circ} \mathrm{C}\right)$ fetal bovine serum (FBS) and 25 $\mathrm{mM}$ Hepes, and was adjusted to $\mathrm{pH} 7.2$ by bicarbonate solution. The cultures were incubated for $72 \mathrm{~h}$.

\section{MTT assay}

The MTT (3-(4, 5-dimethyl thiazol-2-yl)-2, 5diphenyl tetrazolium bromide) assay was used to determine the cytotoxicity of extract. Lung cancer cell line (A549), cervical cancer ( $\mathrm{SiHa}$ and HeLa), skin cancer (A375) were used for testing. MTT assay is based on the ability of mitochondrial dehydrogenase enzyme from viable cells to cleave the tetrazolium rings of the pale yellow MTT and to form dark blue formazan crystals which are largely impermeable to cell membranes, thus resulting in its accumulation within healthy cells. Solubilization of the cells by the addition of a detergent results in the liberation of the crystals. The number of surviving cells is directly proportional to the level of the formazan product formed. The color can then be quantified by a simple colorimetric assay using a multi-well scanning spectrophotometer (ELISA reader). Briefly, cells (5 ${\mathrm{X} 10^{3}}^{3}$ /well) were seeded in $0.2 \mathrm{ml}$ of the medium (DMEM with $10 \%$ PBS) in 96 well plates, treated with drugs for $72 \mathrm{~h}$. and after incubation, cytotoxicity was measured. For this after removing the drug containing media, $25 \mu \mathrm{L}$ of MTT solution $(5 \mathrm{mg} / \mathrm{ml}$ in PBS) and $75 \mu \mathrm{L}$ of complete medium were added to wells (untreated and treated) and incubated for $2 \mathrm{~h}$. At the end of incubation MTT lysis buffer was added to the wells $(0.1 \mathrm{ml} /$ well) and incubated for another $4 \mathrm{~h}$. at $37^{\circ} \mathrm{C}$. At the end of incubation, the optical densities at $570 \mathrm{~nm}$ were measured using a plate reader (Bio-Rad). The relative cell viability in percentage was calculated [A ${ }_{570}$ of treated sample/A ${ }_{570}$ of untreated sample x100] (Anto et al., 2003).

\section{Acridine orange/ ethidium bromide (AO/EB) staining}

The A375 cells were plated in 96-well dishes at a concentration of $5 \times 10^{3}$ cells/well, each containing $100 \mu \mathrm{l}$ of DMEM medium. After $24 \mathrm{~h}$ treatments with extract, cell culture medium was removed and cells were washed with PBS buffer twice and then $100 \mu \mathrm{l}$ of the same buffer were added. Four $\mu \mathrm{l}$ of ethidium bromide and acridine orange (AO/EB) solution (1 part of $100 \mu \mathrm{g} / \mathrm{ml} \mathrm{AO}$ in PBS and 1 part of $100 \mu \mathrm{g} / \mathrm{ml} \mathrm{EB}$ in PBS) were then added. Within 16-18 $\mathrm{h}$ cells were examined in a fluorescence 
microscope and photographed for the presence of apoptotic cells.

\section{Results}

\section{Fluorescence analysis}

Fluorescence analysis of dried powder of $P$. heterophylla was noted under visible light, short UV and long UV which signifies their colour characteristics and purity. The varying colour characteristics observed for different chemicals are given in Table 1.

\section{Phytochemical analysis}

Preliminary qualitative phytochemical evaluation was performed for chloroform, methanol and aqueous extracts of $P$. heterophylla leaves. The results obtained indicated that the crude methanol and aqueous extracts predominantly showed the presence of carbohydrates and secondary metabolites like cardiac glycoside, saponins, flavonoids, phytosterols and phenols than chloroform extract. The chloroform extract showed the presence of cardiac glycoside and coumarin glycoside only (Table 2), while Carbohydrates, saponins, flavanoids, phytosterols and phenols were present in methanol and aqueous extracts.

\section{Phenol and flavonoid contents}

Total phenolic content of the $P$. heterophylla leaf extracts was estimated by using Folin Ciocalteu reagent. The total phenol and flavonoids content were expressed as mg of catechin /g dried extract and $\mathrm{mg}$ of catechol equivalents/g dried extract respectively. Total phenolic content of $P$. heterophylla in aqueous extract was found to be 42.76 and in methanol extract was found to be $44.30 \mathrm{mg} / \mathrm{g}$. Total flavonoid content in aqueous extract was found to be $25.23 \mathrm{mg} / \mathrm{g}$ and in methanol extract was found to be $22.66 \mathrm{mg} / \mathrm{g}$ (Table 3). The tested plant material contained appreciable amounts of phenolic and flavonoid contents.

Table 1. Fluorescence analysis of dried powder of P. heterophylla.

\begin{tabular}{lllll}
\hline Sl. No. & Chemical/solvent & Visible light & Short UV & Long UV \\
\hline 1 & Powder as such & Dark Green & Green & Black \\
2 & Methanol & Dark Green & Dark green & Red \\
3 & Acetic acid & Brown & Dark green & Pinkish red \\
4 & Petroleum ether & Dark Green & Dark green & Red \\
5 & Water & Dark Green & Blackish green & Black \\
6 & $1 \mathrm{~N} \mathrm{NaOH}$ & Dark Brown & Dark greenish black & Black \\
7 & $50 \% \mathrm{HNO}_{3}$ & Brown & Dark green & Black \\
8 & $1 \mathrm{~N} \mathrm{HCl}$ & Green & Dark Green & Black \\
9 & $5 \% \mathrm{FeCl}_{3}$ & Black & Black & Black \\
10 & $1 \mathrm{~N} \mathrm{NaOH} \mathrm{in} \mathrm{water}$ & Green & Green & Pink \\
11 & Chloroform & Dark green & Dark Green & Black \\
12 & Acetone & Green & Greenish black & Black \\
13 & $5 \% \mathrm{H}_{2} \mathrm{SO}_{4}$ & Dark green & Dark green & Pink \\
14 & $5 \% \mathrm{KOH}^{2}$ & Green & Dark green & Black \\
\hline
\end{tabular}

Table 2. Phytochemical analysis of extracts of $P$. heterophylla leaf.

\begin{tabular}{|c|c|c|c|c|c|}
\hline \multirow{2}{*}{$\begin{array}{l}\text { Sl. } \\
\text { No. }\end{array}$} & \multirow{2}{*}{ Tests } & \multirow{2}{*}{ Method } & \multicolumn{3}{|c|}{ Presence (+) or absence (-) phytochemicals } \\
\hline & & & Chloroform & Methanol & Aqueous \\
\hline 1 & Carbohydrates & Molisch's test & - & + & + \\
\hline 2 & Alkaloids & Wagners test & - & - & - \\
\hline 3 & Cardiac Glycoside & Keller killiani test & + & + & - \\
\hline 4 & Coumarin glycoside & Made alkaline & + & - & - \\
\hline 5 & Saponins & Foam test & - & + & + \\
\hline 6 & Flavanoids & Alkaline reagent test & - & + & + \\
\hline 7 & Phytosterols & Salkowski test & - & + & + \\
\hline 8 & Fats \& oil & Spot test & - & - & - \\
\hline 9 & Phenols & Ferric Chloride test & + & + & + \\
\hline 10 & Tannins & Braymer's test & - & - & - \\
\hline 11 & Proteins & Ninhydrin test & - & - & - \\
\hline
\end{tabular}


Table 3. Phenolic and flavonoid contents of P. heterophylla.

\begin{tabular}{lll}
\hline Extract & $\begin{array}{l}\text { Phenols (mg of catechin } \\
\text { equivalents/1g dried extract) }\end{array}$ & $\begin{array}{l}\text { Flavanoids (mg of catechol } \\
\text { equivalents / 1g dried extract) }\end{array}$ \\
\hline Aqueous & 42.76 & 25.23 \\
Methanol & 44.30 & 22.66 \\
\hline
\end{tabular}

\section{Percentage extractive of plant extracts}

Cold extraction process with different solvents such as hexane, chloroform, dichloromethane, ethyl acetate, acetone, methanol, water and the soluble extractive values are given in table 4 . The methanol soluble and water soluble extractive values were found to be $7.5 \%$ and $5.77 \%$ respectively. The methanol soluble and water soluble values indicated the presence of additional methanol soluble and water soluble constituents in the plant. Hexane, chloroform, dichloromethane, ethyl acetate and acetone soluble extractive values were found in negligible quantities.

Table 4. Percentage extractive of leaf extract of $P$. heterophylla.

\begin{tabular}{llllllll}
\hline Extract type & $\begin{array}{l}\text { Hexane } \\
\text { (\%) }\end{array}$ & $\begin{array}{l}\text { Chloroform } \\
\text { (\%) }\end{array}$ & $\begin{array}{l}\text { Dichloro } \\
\text { methane (\%) }\end{array}$ & $\begin{array}{l}\text { Ethyl } \\
\text { acetate (\%) }\end{array}$ & $\begin{array}{l}\text { Acetone } \\
\text { (\%) }\end{array}$ & $\begin{array}{l}\text { Methanol } \\
\text { (\%) }\end{array}$ & $\begin{array}{l}\text { Distilled } \\
\text { Water (\%) }\end{array}$ \\
\hline Cold & 0.12 & 1.81 & 0.67 & 0.47 & 0.45 & 7.50 & 5.77 \\
\hline
\end{tabular}

\section{Antibacterial assay}

Among the seven extracts, the methanol extract exhibited potent activity against all the micro organisms tested. The methanol extract manifested highest activity for $E$. coli and $B$. subtilis with a zone of inhibition of $12 \mathrm{~mm}$ (Table 5). The lowest effect was observed against $K$. pneumoniae, $P$. mirabilis and $S$. epidermidis with a zone of inhibition $10 \mathrm{~mm}$, respectively. The diameter of inhibition zones against $B$. cereus, $P$. aeruginosa and $S$. typhi was $11 \mathrm{~mm}$ each for methanol extract. Hexane extract showed antibacterial activity only against $E$. coli with an inhibitory zone of $10 \mathrm{~mm}$. The other extracts such as chloroform, dichloromethane, ethyl acetate, acetone and aqueous extracts failed to show any activity against the eight micro organisms tested. Methanol extract was found to be the most active against all the bacterial pathogens tested but exhibited comparatively low activity when compared with the control antibiotic ciprofloxacin.

Table 5. Antibacterial activity of different extracts ('-' no activity).

\begin{tabular}{|c|c|c|c|c|c|c|c|c|}
\hline $\begin{array}{l}\text { Extraction } \\
\text { solvents } \\
\end{array}$ & E. coli & $\begin{array}{l}\text { K. } \\
\text { pneumoniae }\end{array}$ & $\begin{array}{l}P . \\
\text { mirabilis }\end{array}$ & $\begin{array}{l}\text { S. } \\
\text { epidermidis }\end{array}$ & $\begin{array}{l}\text { B. } \\
\text { cereus }\end{array}$ & $\begin{array}{l}P . \\
\text { aeruginosa }\end{array}$ & $\begin{array}{l}\text { B. } \\
\text { subtilis }\end{array}$ & $\begin{array}{l}\text { S. } \\
\text { typhi }\end{array}$ \\
\hline Hexane & $10 \pm 1.24$ & Nil & Nil & Nil & Nil & Nil & Nil & Nil \\
\hline Chloroform & Nil & Nil & Nil & Nil & Nil & Nil & Nil & Nil \\
\hline Dichloromethane & Nil & Nil & Nil & Nil & Nil & Nil & Nil & Nil \\
\hline Ethyl acetate & Nil & Nil & Nil & Nil & Nil & Nil & Nil & Nil \\
\hline Acetone & Nil & Nil & Nil & Nil & Nil & Nil & Nil & Nil \\
\hline Methanol & $12 \pm 0.81$ & $10 \pm 1$ & $10 \pm 0$ & $10 \pm 1$ & $11 \pm 0$ & $11 \pm 0.82$ & $12 \pm 1$ & $11 \pm 0$ \\
\hline Water & Nil & Nil & Nil & Nil & Nil & Nil & Nil & Nil \\
\hline $\begin{array}{l}\text { Ciprofloxacin } \\
(5 \mu \mathrm{g} / \mathrm{ml})\end{array}$ & $32 \pm 1.15$ & $28 \pm 1.52$ & $31 \pm 0.57$ & $29 \pm 1$ & $27 \pm 1$ & $30 \pm 0$ & $26 \pm 0$ & $30 \pm 1.52$ \\
\hline
\end{tabular}

\section{Minimum inhibitory concentration}

MIC values were determined for the five pathogenic organisms against which positive antibacterial activity was observed. They are B. subtilis, B. cereus, E. coli, S. epidermidis and $K$. pneumoniae and results are presented in table 6 . The microorganism that exhibited highest sensitivity towards extract was $B$. subtilis $(125 \mu \mathrm{g} / \mathrm{ml})$ followed by $B$. cereus $(250 \mu \mathrm{g} / \mathrm{ml})$ and $K$. pneumoniae $(250 \mu \mathrm{g} / \mathrm{ml})$. $E$. coli exhibited an MIC of $500 \mu \mathrm{g} / \mathrm{ml}$, whereas $S$. epidermidis exhibited an MIC of $2000 \mu \mathrm{g} / \mathrm{ml}$. It appeared that effective MIC also represents the effective bactericidal concentration of the bacteria tested. The activity of the extract was lower than that of control drug ciprofloxacin. 
Table 6. MIC value of the extract against bacteria.

\begin{tabular}{lll}
\hline Test organisms & \multicolumn{2}{l}{$\mathrm{MIC}(\mu \mathrm{g} / \mathrm{ml})$} \\
\cline { 2 - 3 } & Extract & Ciprofloxacin \\
\hline B. subtilis & 125 & 0.5 \\
B. cereus & 250 & 1 \\
K. pneumoniae & 250 & 1 \\
E. coli & 500 & 0.5 \\
S. epidermidis & 2000 & 2 \\
\hline
\end{tabular}

\section{Time kill assay}

The time kill assay was conducted to determine the rates at which test bacteria was killed by exposing to extract and antibiotic. Time kill assays for $E$. coli, S. epidermidis, K. pneumoniae, B. subtilis and $B$. cereus were shown in figures $1,2,3,4,5$ respectively. All bacteria recorded significant reduction of growth between 4 and $12 \mathrm{~h}$. Re growth was not observed for test bacteria treated with extract.

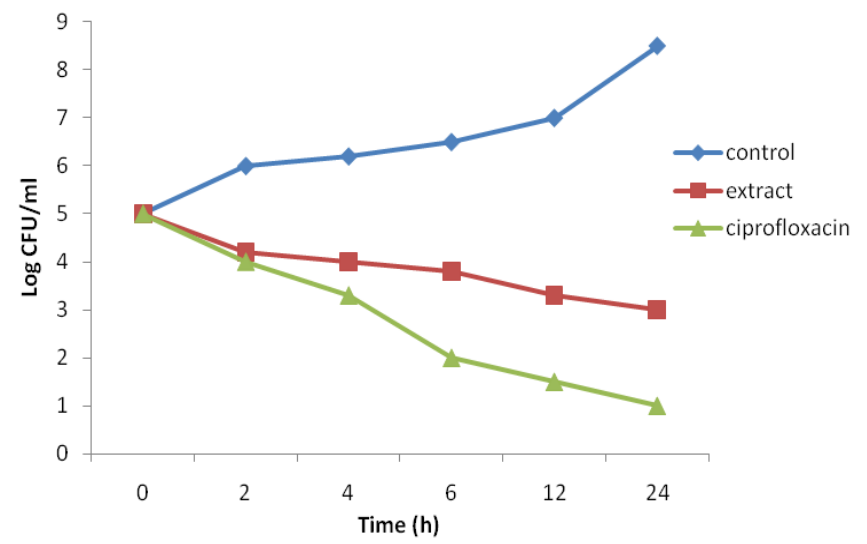

Fig. 1: Time kill assay of extract against E. coli.

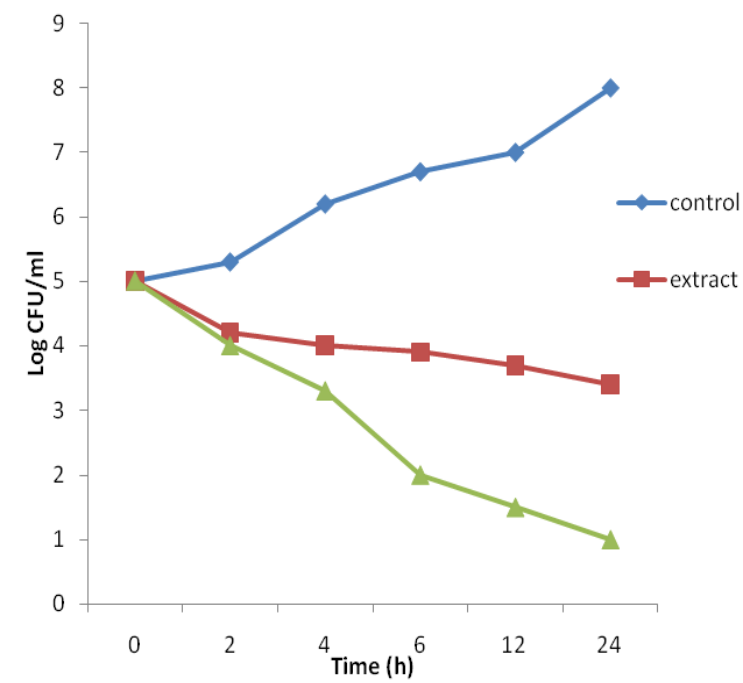

Fig. 2: Time kill assay of extract against $S$. epidermidis.

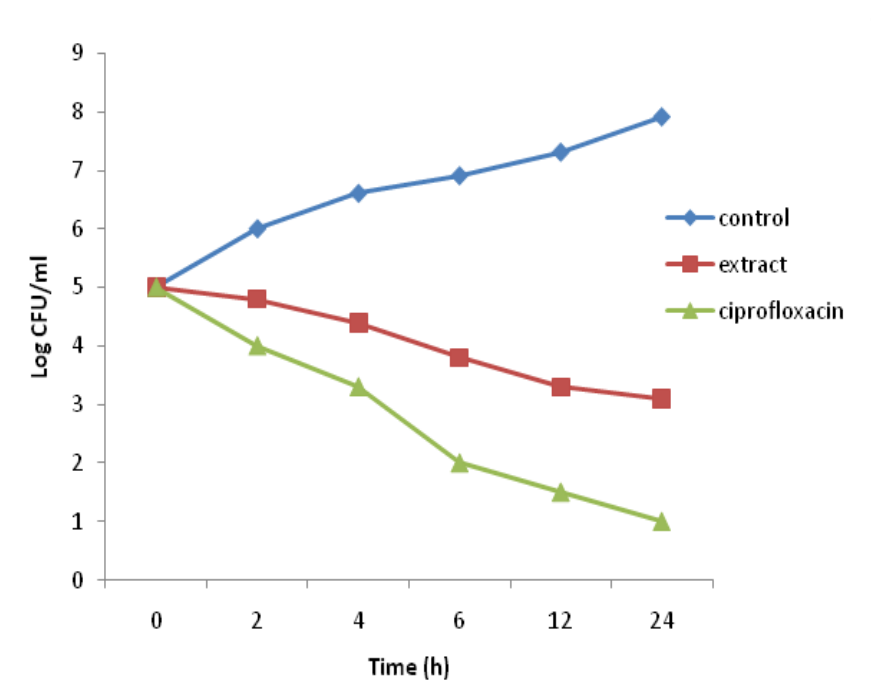

Fig. 3: Time kill assay of extract against $K$. pneumoniae.

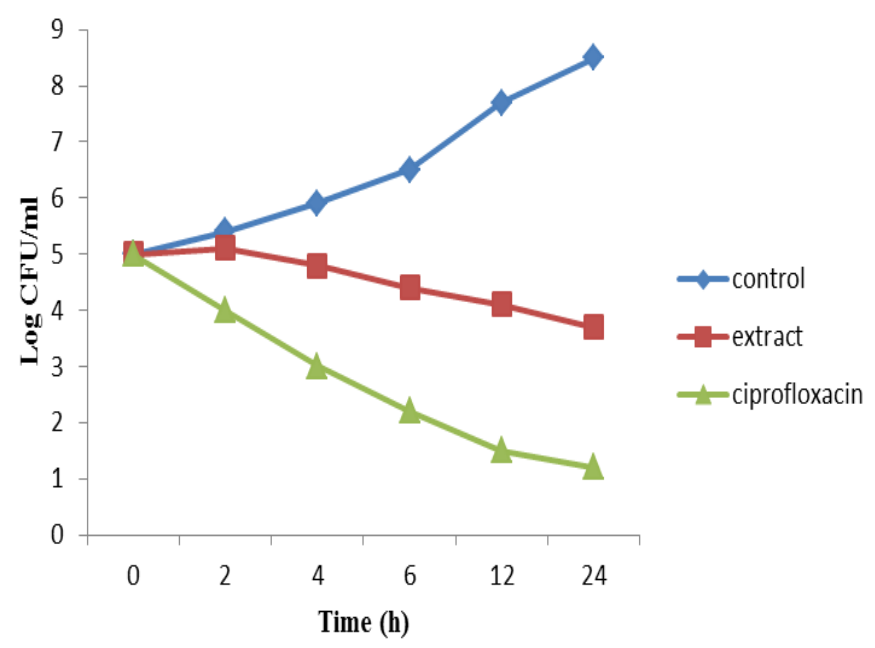

Fig. 4: Time kill assay of extract against B. subtilis.

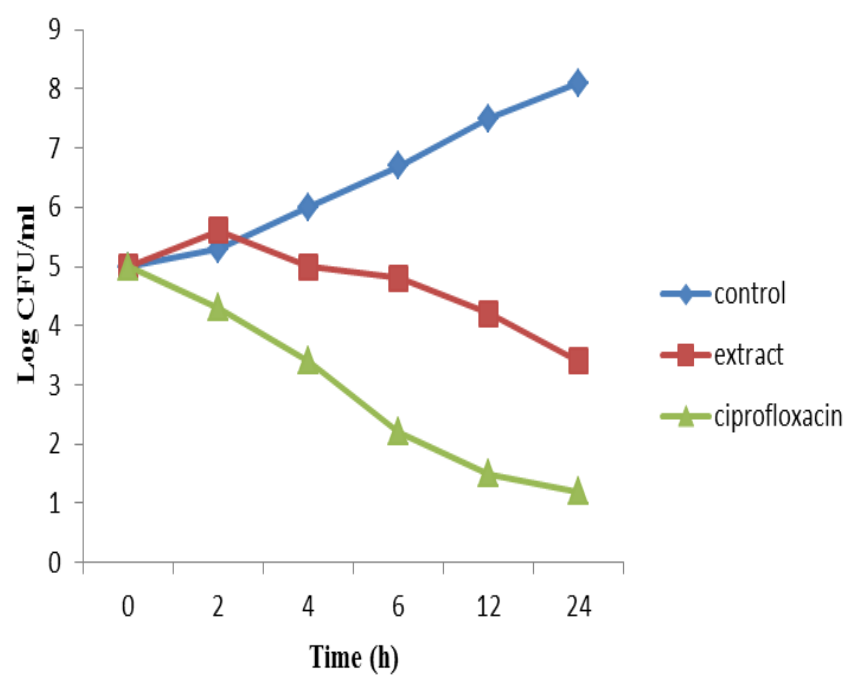

Fig. 5: Time kill assay of extract against B. cereus. 


\section{In vitro antioxidant assays}

Antioxidant activity of the two (aqueous and methanol) extracts of leaves of $P$. heterophylla varying concentrations ranging from 10- 2000 $\mu \mathrm{g} / \mathrm{ml}$ was evaluated by various in vitro models.

\section{DPPH radical scavenging activity}

The antiradical scavenging ability of $P$. heterophylla methanol and aqueous extract on DPPH was $71.96 \%$ and $60.22 \%$ respectively at a concentration of $1000 \mu \mathrm{g} / \mathrm{ml}$ (Figure 6). The standard BHA exhibited $98 \%$ radical scavenging ability at $100 \mu \mathrm{g} / \mathrm{ml}$ concentration itself, which was comparatively high. The $\mathrm{IC}_{50}$ values of methanol and aqueous extracts for DPPH radical scavenging activity were 542.42 and $808.88 \mu \mathrm{g} / \mathrm{ml}$ respectively.

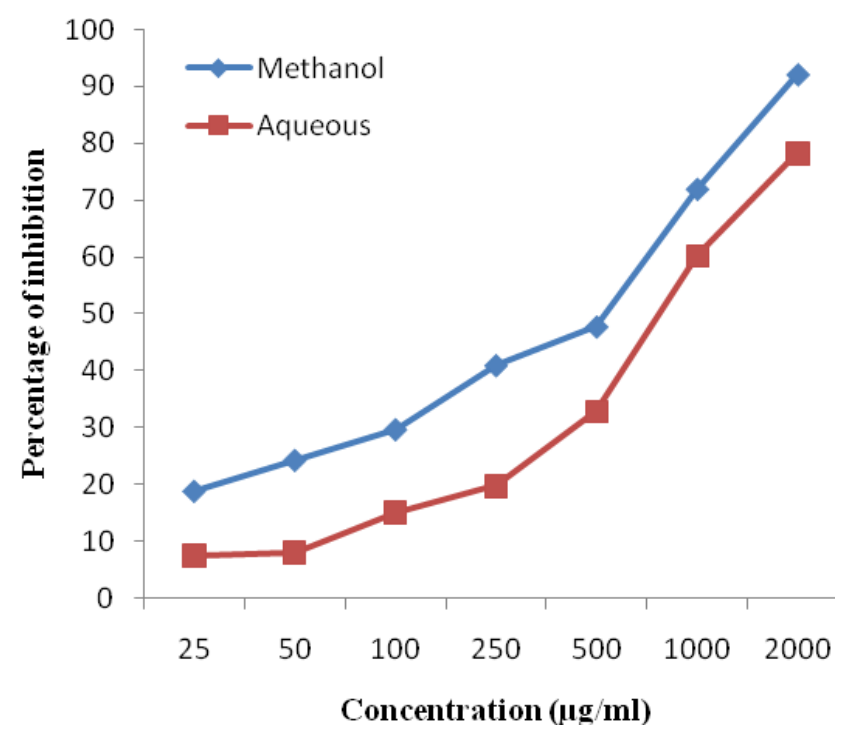

Fig. 6: DPPH radical scavenging activity of extracts.

\section{Metal ion chelating activity}

The percentage of inhibition of aqueous and methanol extract was found to be $56.84 \%$ and $78.66 \%$ respectively at concentration $1000 \mu \mathrm{g} / \mathrm{ml}$ (Figure 7) whereas, the standard BHA showed 82 $\%$ inhibition at concentration $100 \mu \mathrm{g} / \mathrm{ml}$. The result of the present study suggested that the aqueous extract exhibited good chelating activity on ferrous ions than the methanol extract. The $\mathrm{IC}_{50}$ value of methanol and aqueous extract was found to be 701 and $399.68 \mu \mathrm{g} / \mathrm{ml}$ respectively.

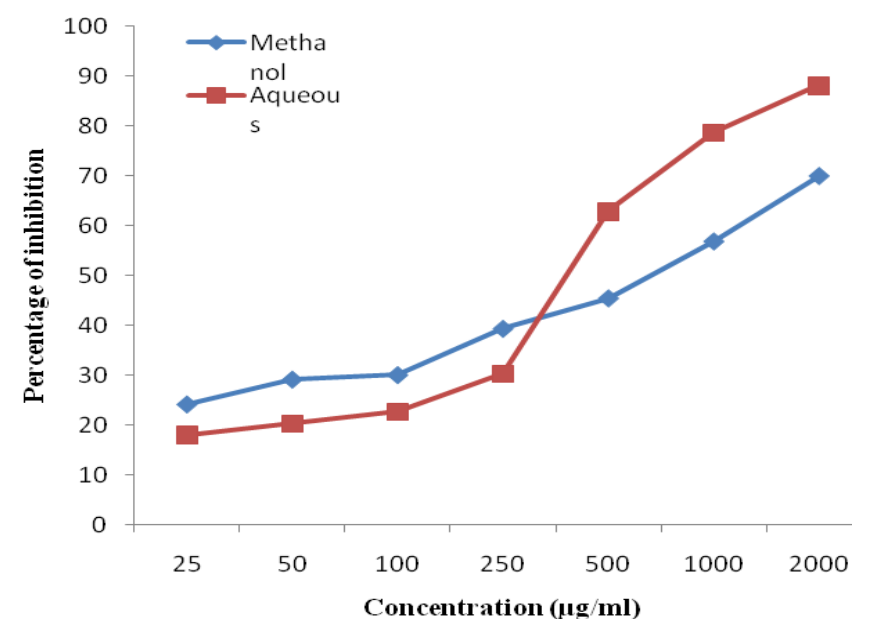

Fig. 7: Metal ion chelating activity of extracts.

\section{Reducing power activity}

Reducing power of both aqueous and methanol extracts increased with an increase in concentration. The reducing power of the extracts was found to be dose dependent (Figure 8). The methanol extract showed potent reducing ability than the aqueous extract. The standard BHA showed more reductive ability than that of the extracts.

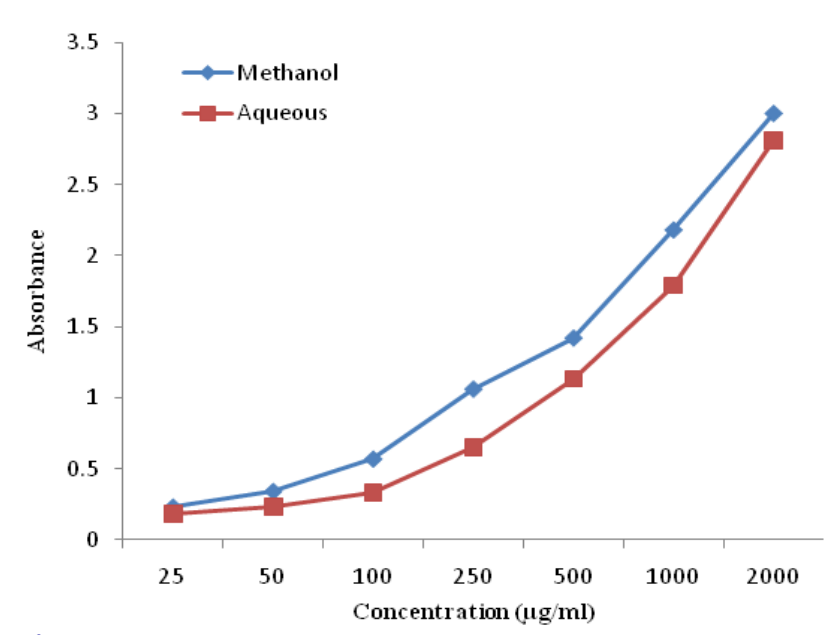

Fig. 8: Reducing power activity of extracts.

\section{Superoxide radical scavenging assay}

The superoxide radical scavenging ability of methanol and aqueous extracts was $37.88 \%$ and $43.98 \%$ (Figure 9) respectively at $1000 \mu \mathrm{g} / \mathrm{ml}$. The standard BHA exhibited $82 \%$ inhibition of superoxide radicals at $100 \mu \mathrm{g} / \mathrm{ml}$ concentration which showed a wide variation when compared to the extracts. 


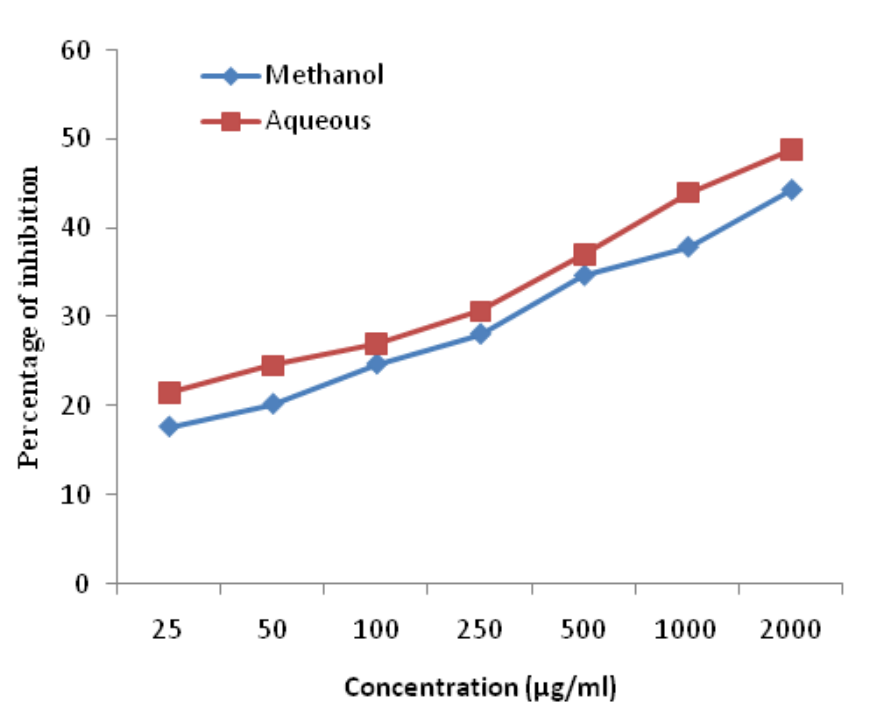

Fig. 9: Superoxide radical scavenging activity of extracts.

\section{Lipid peroxidation assay}

The aqueous extract exhibited more lipid peroxidation inhibition ability with $52.96 \%$ (Figure 10) than the methanol extract (80.36 \%) at concentration $1000 \mu \mathrm{g} / \mathrm{ml}$. The standard quercetin showed $64 \%$ inhibition at $100 \mu \mathrm{g} / \mathrm{ml}$ concentrations. The IC ${ }_{50}$ values of methanol and aqueous extracts were found to be 55 and 869.15 $\mu \mathrm{g} / \mathrm{ml}$ respectively.

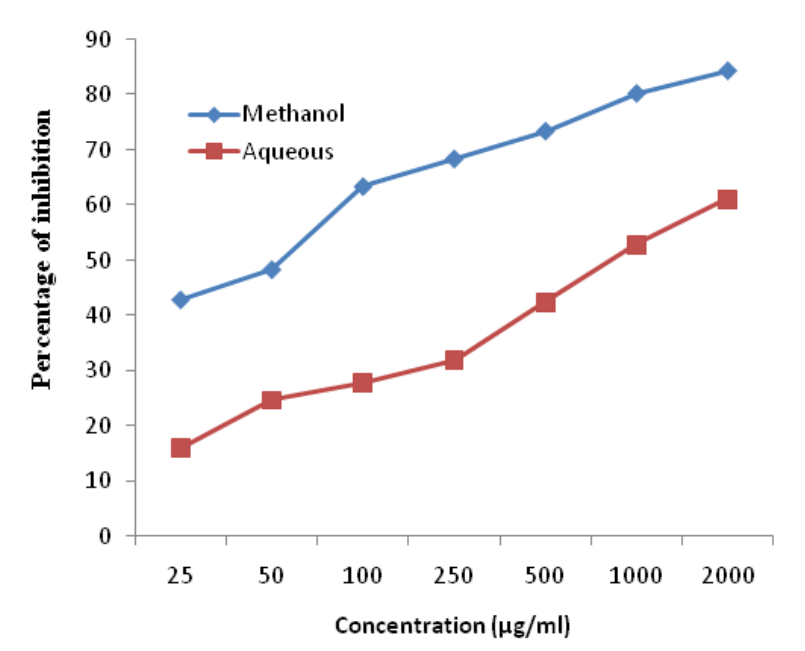

Fig. 10: Lipid peroxidation activity of extracts

\section{Hydroxyl radical scavenging activity}

At $1000 \mu \mathrm{g} / \mathrm{ml}$, the methanol extract was found to exhibit better inhibition of $43.81 \%$ (Figure 11) compared to aqueous extract (55.06 \%) with an
$\mathrm{IC}_{50}$ value of $529.7 \mu \mathrm{g} / \mathrm{ml}$. The scavenging activity obtained for BHA was $59 \%$ at concentration 100 $\mu \mathrm{g} / \mathrm{ml}$.

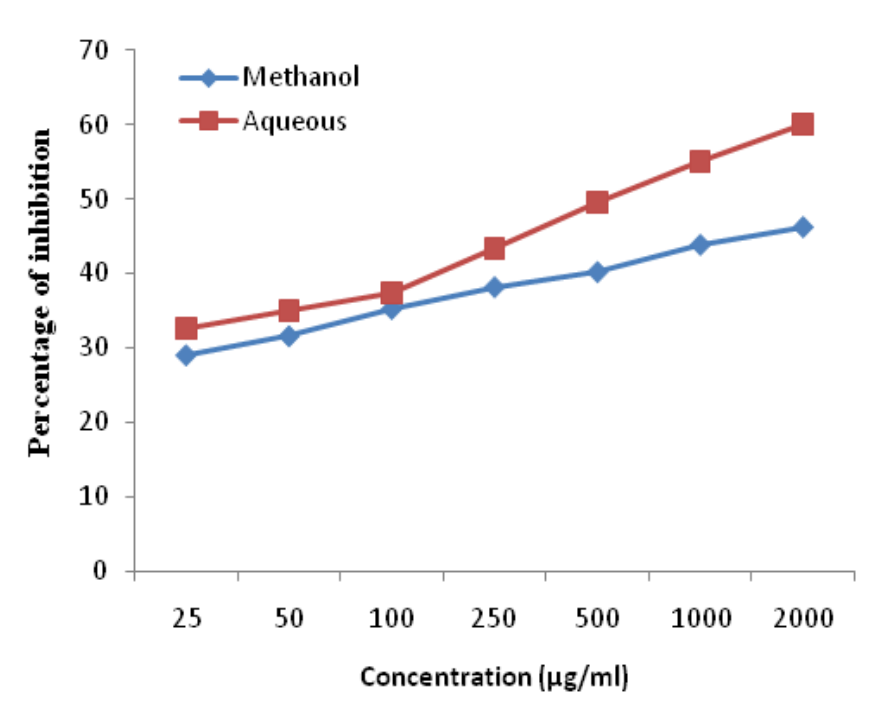

Fig. 11: Hydroxyl radical scavenging activity of extracts.

\section{Nitric oxide radical inhibition activity}

The nitric oxide radical inhibition activity of ethyl acetate extract is shown in figure 12. The scavenging of nitric oxide by ethyl acetate extract was increased in a dose-dependent manner. Approximately $50 \%$ of nitric oxide was scavenged at the concentration of $500 \mu \mathrm{g} / \mathrm{ml}$. The nitric oxide radical inhibition of BHA is superior to that of the extract.

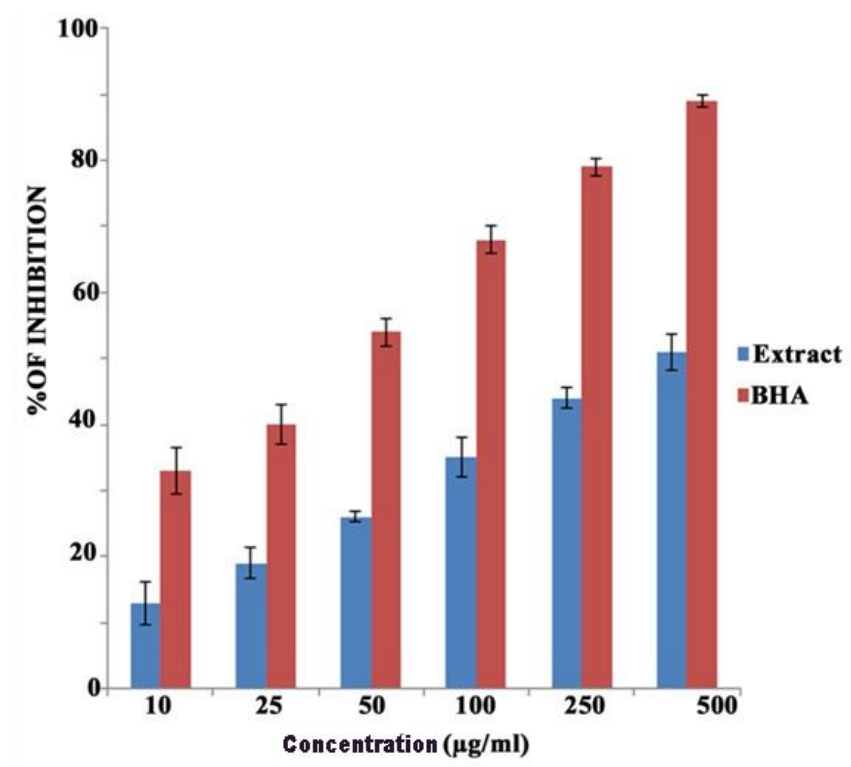

Fig. 12: Nitric oxide radical activity of extract. 


\section{Cytoxicity analysis}

Cell viability assay was determined by MTT assay after $72 \mathrm{~h}$ of treatment. A dose-dependent growth inhibition in cell lines was observed. A375 cells turned out to be the most sensitive cell line to the ethyl acetate crude extract $\left(\mathrm{IC}_{50}-250 \mu \mathrm{g} / \mathrm{ml}\right)$, so it was selected for further analysis (Figure 13).

Cis-DDP was used as the positive control. Hexane extract recorded no activity whereas methanol extract recorded slight activity against the cell lines.

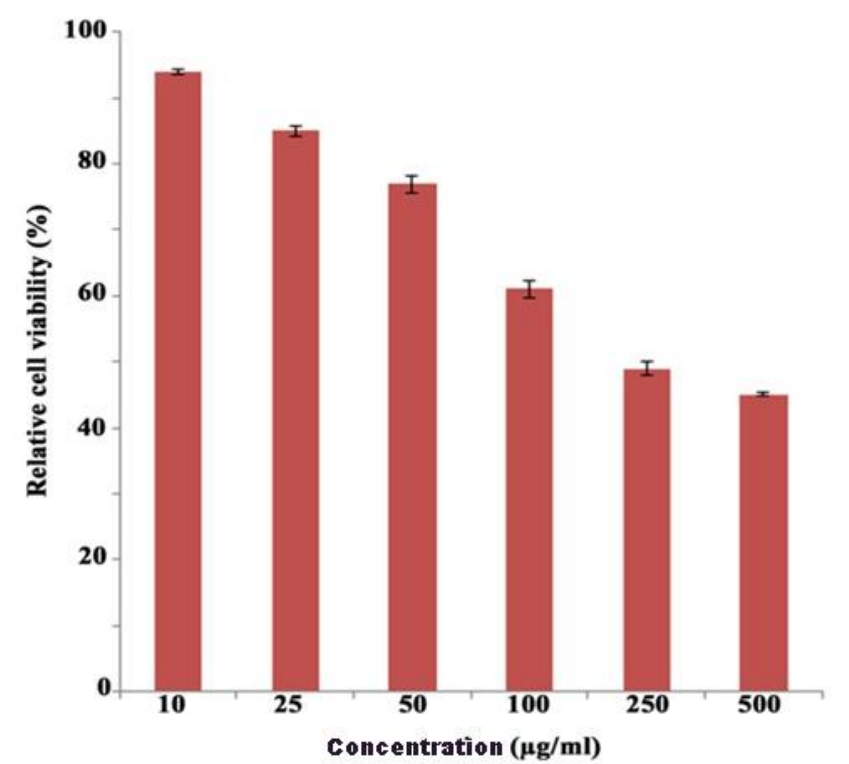

Fig. 13: MTT assay of ethyl acetate extract against A375 cell line.

\section{Acridine orange/ ethidium bromide (AO/EB) staining}

The morphological study showed chromatin condensation and blebbing in A375 (Figure 14) when treated with $250 \mu \mathrm{g} / \mathrm{ml}$ extract. When A375 cell was stained with $\mathrm{AO} / \mathrm{EB}$, an increase of orange-stained cells with nuclear condensation was clearly observed in both A549 cell line. When A375 cell was treated with the different doses of the extract, morphological changes of the cell was detected by acridine orange staining.

Apoptotic cells showing DNA segmentation of nucleus were counted and inhibition of apoptosis was then calculated for the average of three independent determinations.

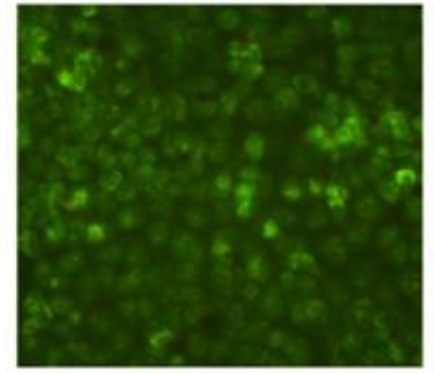

Control

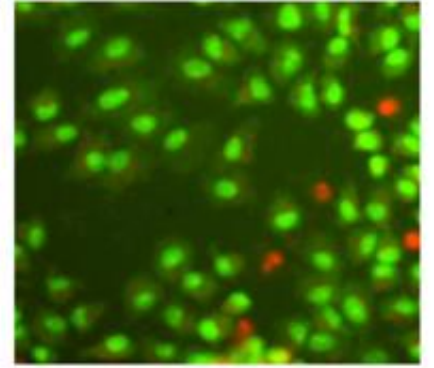

$250 \mu \mathrm{g} / \mathrm{ml}$
Fig. 14: Acridine - orange ethidium bromide staining.

\section{Discussion}

Fluorescence analysis of $P$. heterophylla helped in the identification, authentication and was useful in making a monograph of the plant material. This will also act as a tool to detect adulterants and substituent and will help in maintaining the quality, reproducibility and efficacy of natural drugs (Chanda 2004). The preliminary qualitative phytochemical screening revealed the presence of various bioactive compounds of which the carbohydrates and secondary metabolites, like cardiac glycoside, saponins, flavonoids, phytosterols and phenols were most prominent. Mithraja et al., 2012 reported the presence of carbohydrates, phenols, coumarins, saponins, steroids, tannins, xanthoproteins and absence cardiac glycoside, flavonoids, and phytosterols in $P$. heterophylla. These findings are totally in agreement with the present study. The aqueous extract is found to be a good source of phenols and flavonoids. Previous studies found that phenolic compounds are the prominent free radical terminators and responsible for exhibiting multiple medicinal and physiological functions in animals as well as in plants (Manach et al., 2005). Similarly, flavonoids are the important polyphenolic class exhibits a wide range of biological effects including antibacterial, antiinflammatory, antiallergic, antithrombotic, and vasodilatory actions (Rahmatullah et al., 2010).

In antibacterial analysis, the methanol extract exhibited significant zone of inhibition against both gram positive and gram negative bacteria. Except methanol and hexane extract, no other extracts showed antibacterial activity against the pathogenic microorganism tested. The maximum zone of inhibition was observed for E. coli (12 mm) and $B$. subtilis $(12 \mathrm{~mm})$. The inhibitory action of 
the leaf against both gram positive and gram negative strains indicated the presence of broadspectrum antibiotic compounds in the plant (Siddhuraju and Becker, 2003).

Somchit et al. (2011), reported antibacterial activity of $P$. heterophylla leaf extracts (aqueous, ethanol and chloroform) against four bacterial strains (E. coli, S. aureus, $K$. pneumoniae, $B$. subtilis and $S$. enteritidis) and reported that the aqueous extract showed potent antibacterial activity against the above said microorganisms. However in the present study the aqueous extract did not show any antibacterial activity and only the methanol and hexane extract showed activity against the test microorganisms.

MIC was done with methanol extract, which showed broad spectrum antibacterial activity, against $B$. subtilis, $B$. cereus, $E$. coli, $S$. epidermidis and $K$. pneumoniae. The highest MIC value was observed for $B$. subtilis indicating a significant antibacterial activity and the lowest was found in $S$. epidermidis. It was already reported that if the extract displays an MIC value less than $100 \mu \mathrm{g} / \mathrm{ml}$, the antimicrobial activity was good; from 100 to $500 \mu \mathrm{g} / \mathrm{ml}$ the antimicrobial activity was referred to as moderate, from 500 to $1000 \mu \mathrm{g} / \mathrm{ml}$ the antimicrobial activity was considered as weak and over $1000 \mu \mathrm{g} / \mathrm{ml}$ the extract was considered inactive (Holetz FoBr et al., 2002).

The methanol extract of $P$. heterophylla exhibited a significant dose dependent inhibition of DPPH activity than the aqueous extract. This result suggests that the plant extract is a good DPPH radical scavenger but the efficiency is low when compared to standard BHA. It has been found that cysteine, glutathione, ascorbic acid, tocopherol, poly-hydroxyl aromatic compounds etc. reduce and decolourize DPPH by their hydrogen donating ability (Blois, 1958). The antioxidant activity of the extracts correlated well with the total phenolic contents and indicated that phenolic compounds are dominant contributors to antioxidant activity of the extracts. In the metal ion chelating assay, the crude methanol extract exhibited more $\mathrm{Fe}^{2+}$ ion chelating ability than the aqueous extract. Transition metals such as ferrous ion can stimulate lipid peroxidation by generating hydroxyl radicals and as well as by decomposing lipid hydroperoxides into peroxyl and alkoxyl radicals therefore drive the chain reaction of lipid peroxidation (Zhao et al., 2008). The activity of methanol extract in this assay may be due to flavonoids, which have the potential positive effect on cardiovascular system, most likely due to their ability to chelate iron thus inhibiting the generation of reactive oxygen species (Mladenka et al., 2010).

In reducing power assay, the methanol extract exhibited powerful reductive potential when compared to aqueous extract. The reductive ability of compounds may act as a significant indicator of their potential free radical scavenging activity. The free radical scavengers present in the leaf extracts would result in the transformation of $\mathrm{Fe}^{3+}$ to $\mathrm{Fe}^{2+}$ by donating an electron in the reducing power assay. The quantity of $\mathrm{Fe}^{2+}$ complex can be then be determined by measuring the formation of Perl's Prussian blue at 700nm (Ebrahimzadeh et al., 2008). The hydroxyl radical is the most powerful free radical and has the ability to initiate DNA strand breakage which leads to carcinogenesis, mutagenesis, and cytotoxicity (Chatgilialoglu and O'Neill, 2001). Out of the two extract analysed, the methanol extract was found to be the best in quenching the hydroxyl radicals produced in the reaction mixture with an $\mathrm{IC}_{50}$ value of $529.73 \mu \mathrm{g} / \mathrm{ml}$.

In lipid peroxidation assay the thiobarbituric acid reactive substance formation analysis was done to determine the inhibition of $\mathrm{Fe}^{2+}$-induced lipid peroxidation by the leaf extracts. The highest antilipid peroxidation action was found in methanol extract against goat liver samples than aqueous extract. The methanol extract had potent lipid peroxidation inhibitory activity with an $\mathrm{IC}_{50}$ value of $55 \mu \mathrm{g} / \mathrm{ml}$. Polyphenolic compounds like flavonoid plays a major role in stabilizing lipid peroxidation and are also associated with antioxidant potential of the plant (Cook and Samman, 1996). Superoxide radicals are produced from molecular oxygen due to oxidative enzymes present in body as well as through non-enzymatic reaction such as autoxidation by catechol amines (Sainani, 1997). Both aqueous and alcoholic extracts produced almost similar superoxide radical scavenging ability which was relatively low when compared to other antiradical scavenging assays conducted. The aqueous extract was found to be more effective in quenching superoxide radical generated by photo reduction of riboflavin 
than methanol extract. In ethyl acetate extract of $P$. heterophylla , 50\% of nitric oxide was scavenged approximately at the concentration of $500 \mu \mathrm{g} / \mathrm{ml}$. Chandran et al. (2013), performed a similar analysis in Aegle tamilnadensis ethyl acetate extract and observed 50\% of nitric oxide was scavenged approximately at the concentration of $200 \mu \mathrm{g} / \mathrm{ml}$.

The cytotoxicity studies on four cell lines tested, A375 cells turned out to be the most sensitive cell line to the ethyl acetate crude extract $\left(\mathrm{IC}_{50}-250\right.$ $\mu \mathrm{g} / \mathrm{ml}$ ) of $P$. heterophylla . Endrini 2009, determined the anticarcinogenic properties of $D$. piloselloides (synonym of $P$. heterophylla), by the MTT assay on the human breast carcinoma dependent- hormone (MCF-7) cell lines. The results showed that the extract displayed cytotoxic effects against $\mathrm{MCF}-7$ with $\mathrm{IC}_{50}$-value of 83.63 $\mu \mathrm{g} / \mathrm{ml}$. The $D$. piloselloides extract was found to have high antioxidant activity with $\mathrm{IC}_{50}$-value of 4.229 ppm. Sahid et al., 2013, evaluated the cytotoxicity assay of $D$. piloselloides leaf methanol extract by the MTT test on leukemia cells P388. The result showed that methanol extract of $D$. piloselloides leaf had cytotoxic effects against leukemia cells and inhibition of 50\% leukemia growth $\left(\mathrm{IC}_{50}\right.$ value) was $19.32 \mu \mathrm{g} / \mathrm{ml}$.

Wulandari et al. (2013), evaluated the cytotoxic effects of Pyrrosia piloselloides (synonym of $P$. heterophylla) on MCF-7 Breast cancer cell lines using MTT assay. Hexane, dichloromethane and methanol extracts were used for the study. The results showed that dichloromethane extract has the potential as an antioxidant with the smallest $\mathrm{IC}_{50}$ value of $12.82 \mu \mathrm{g} / \mathrm{ml}$ and cytotoxicity with $\mathrm{IC}_{50}$ value of $39.54 \mu \mathrm{g} / \mathrm{ml}$. In the present study the A375 cell lines were found to be the most sensitive cell line to the ethyl acetate crude extract with $\mathrm{IC}_{50}$ value of $250 \mu \mathrm{g} / \mathrm{ml}$.

\section{Conclusion}

The phytochemical results indicated the presence of phenols, flavonoids, carbohydrates, saponins and phytosterols in both methanol and aqueous extracts. The antibacterial activity of the leaf extracts against the test bacteria showed that methanol extract was most active against the bacterial pathogens ( $E$. coli and $B$. subtilis). These extracts were also found to possess free radical scavenging activities. Ethyl acetate extract exhibited anticancer activity against A375 cell lines. The results obtained in these analyses clearly showed the bioactive potency of the methanol, aqueous and ethyl acetate extract of $P$. heterophylla leaf which can be exploited further. Further studies may be conducted in future to identify the bioactive components in these extracts.

\section{Conflict of interest statement}

Authors declare that they have no conflict of interest.

\section{References}

Aggarwal, B.B., Shishodia, S., 2004. Suppression of the nuclear factor activation pathway by spicederived phytochemicals: reasoning for seasoning. Ann. N Y Acad. Sci, 1030: 434-441.

Anto, R.J.,Venkatraman, M., Karunagaran, D.,

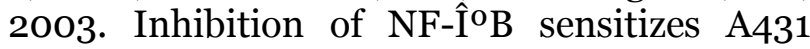
cells to epidermal growth factor-induced apoptosis, whereas its activation by ectopic expression of RelA confers resistance. J. Biol. Chem. 278 (28), 25490-25498.

Ayyanar, M., Ignacimuthu, S., 2005. Traditional knowledge of Kani tribals in Kouthalai of Tirunelveli hills, Tamil Nadu, India. $\mathrm{J}$. Ethnopharmacol. 102(2), 246-255.

Badgujar, N.V., Kinnari,N.Mistry., Rank, D.N., Chaitanya,G.Joshi., 2018. Antiproliferative activity of crude extract and different fractions of Butea monosperma against lung cancer cell line. Indian J. Pharm. Sci. 8o(5), 875-882.

Balandrin, M.F., Kjocke, A., Wurtele, E.,Bollinger, W.H., 1985. Natural plant chemicals: sources of industrial and mechanical materials. Science. 228, 1154-116o.

Bauer, A.W., Kirby, W.M.M., Sherris, J.C.,Turck. M., 1966. Antibiotic susceptibility testing by a standardized single disk method. Am. J. Clin. Pathol. 45(4), 493-496.

Blois, M.S., 1958. Antioxidant determination by the use of stable free radical. Nature. 181, 1199-1200.

Chanda, S., 2014. Importance of pharmacognostic study of medicinal plants: An overview. J. Pharmacogn. Phytochem. 2 (5), 69-73.

Chandran, R.P., Vysakhi, M.V., Manju, S., Kadar S.A., Nair S.A. 2013. In vitro free radical scavenging activity of aqueous and methanolic 
leaf extracts of Aegle tamilnadensis Abdulkader (Rutaceae). Int. J. Pharm. Pharm. Sci. 5 Suppl. 3: 819-823.

Chang, C.C., Yang, M.H., Wen, H.M.,Chern, J.C., 2002. Estimation of total flavonoid content in propolis by two complementary colorimetric methods. J. Food Drug Anal. 10(3), 178-182.

Chatgilialoglu, C., O'Neill, P., 2001. Free radicals associated with DNA damage. Exp. Geront. 36 (9), 1459-1471.

CLSI, 2012. Performance Standards for Antimicrobial Susceptibility Testing: Twentysecond Informational Supplement M10o-S22. Clinical and Laboratory Standards Institute. M10o-S22. CLSI, Wayne, PA, USA.

Cook, N.C., Samman, S., 1996. Flavonoids chemistry, metabolism, cardioprotective effects, and dietary sources. J. Nutr. Biochem. 7(2), 66-76.

Coruh, N., Celep, A.G.S.C., Azgakae, F., 2007. Antioxidant properties of Prangos ferulacea (L.) Lindl., Chaerophyllum macropodum Boiss. and Heracleum persicum Desf. from Apiaceae family used as food in Eastern Anatolia and their inhibitory effects on glutathione-S-transferase. Food Chem. 100(3), 1237-1242.

Ebrahimzadeh, M.A., Hosseinimehr, S.J., Hamidinia, A., Jafari, M., 2008. Antioxidant and free radical scavenging activity of Feijoa sallowiana fruits peel and leaves. Pharmacol. online. 1, 7-14.

Endrini, S., 2009. Antioxidant activity and anticarcinogenic properties of "Sisik Naga" (Drymoglossumn piloselloides Presl.). J. Kedokteran Yarsi, 17 (2), 89-92.

Gulcin, I., 2006. Antioxidant and antiradical activities of L-carnitine. Life Sci. 78(8), 803-811.

Gupta, S.M., Gupta, A.K., Ahmed, Z., Kumar, A., 2011. Antibacterial and antifungal activity in leaf, seed extract and seed oil of Seabuckthorn (Hippophae salicifolia D. Don). Plant J. Plant Pathol. Microbiol. 2, 105.

Halliwell, B., 1994. Free radicals, antioxidants, and human disease: curiosity, cause, or consequence? Lancet. 344, 721-724.

Harborne, J.B., 1973. Phytochemical Methods: guide to modern techniques of plant analysis. Chapman and Hall Ltd, London. pp.49-279.

Holetz, Fo.Br., Pessini, G.L., Sanches,N.Rr., Cortez,Dg.Ac.G., Nakamura, C.V., Dias, Filho, B.P., 2002. Screening of some plants used in the Brazilian folk medicine for the treatment of infectious diseases. Memarias do Instituto Oswaldo Cruz, 97, 1027-1031.

Jayaprakash, G.K., Rao, L.J., 200o. Phenolic constituents from lichen Parmontrema stuppeum. Food Control. 55(11-12), 1018-1022.

Kathiresan, K., Boopathy, N.S., Kavitha, S., 2006. Coastal vegetation- an under explored source of anticancer drugs. Nat. Prod. Rad. 5(2), 115-119.

Kokoshi, G.J., Kokoshi, J.R., Sharma, F.J., 1958. Fluorescence of powdered vegetable drugs under ultra violet radiation. J. Am. Pharm. Assoc. 47 (10), 715-717.

Krishnaraju, A.V., Rao, T.V.N., Sundararaju, D., Vanisree, M., Tsay, H.S.,Subbaraju, G.V., 2005. Assessment of bioactivity of Indian medicinal plants using brine shrimp (Artemia salina) lethality assay. Int. J. Appl. Sci. Engg. 3(2), 125-134.

Kumar, P.P., Raj, J.P.P., Christhudas, I.V.S.N., Jansi, R.S., Raj, M.N.,Agastian, P., 2014. Glucosidase inhibition and antioxidant properties of Streptomyces sp.: In Vitro. Appl. Biochem. Biotechnol. 172(3), 1687-1698.

Malik, C.P., Singh, M.B., 1980. Plant enzymology and histo-enzymology. Kalyani Publishers, Kalyani.

Manach, C., Mazur, A., Scalbert, A., 2005. Polyphenols and prevention of cardiovascular diseases. Curr. Opin. Lipidol. 16(1), 77-84.

Mandal, P., Misra, T.K., Ghosal, M., 2009. Freeradical scavenging activity and phytochemical analysis in the leaf and stem of Drymariadiandra Blume. Int. J. Integr . Biol. 7(2), 80-84.

Maria, Debbarma., Nazir, A.Pal., Munesh, Kumar., Rainer, W.Bussmann., 2017. Traditional knowledge of medicinal plants in tribes of Tripura in northeast, India. Afr. J. Trad. Compl. Altern. Med. 14(4), 156-168.

McCord, J.M., Fridovich, I., 1969. Superoxide dismutase an enzymic function for erythrocuprein (hemocuprein). J. Biol. Chem. 244(22), 6049-6055.

Mithraja, M.J., Irudayaraj, V., Kiruba, S., Jeeva, S., 2012. Antibacterial efficacy of Drynaria quercifolia (L.) J. Smith (Polypodiaceae) against clinically isolated urinary tract pathogens. Asian Pac. J. Trop. Biomed. 2(1), S131-S135.

Mladenka, P., Zatloukalova, L., Filipsky, T.,Hrdina, R., 2010. Cardiovascular effects of flavonoids 
are not caused only by direct antioxidant activity. Free Radic. Biol. Med. 49(6), 963-975.

Neergheen, V., Bahorun, T., Taylor, E., Jen, L.,Aruoma, O., 2009. Targeting specific cell signaling transduction pathways by dietary and medicinal phytochemicals in cancer chemoprevention. Toxicol. 278 (2), 229-241.

Okwu, D.E., 2004. Phytochemicals and vitamin content of indigenous spices of South Eastern Nigeria. J. Sustain. Agric. Environ. 6(1), 30-37.

Orhan, I., Kartal, M., Sezer, M., Senol, F.S., Yilmaz, G.,Sener, B.S., 2009. Free radical scavenging properties and phenolic characterization of some edible plants. Food Chem. 114(1), 276281.

Oyaizu, M., 1986. Studies on products of browning reaction prepared from glucoseamine. Jpn. J. Nutr. Diet. 44 (6), 307-315.

Rahmatullah, M., Rahman, M.A., Hossan, M.S., Taufiq-Ur-Rahman, M., Jahan, R.,Mollik, M.A., 2010. A pharmacological and phytochemical evaluation of medicinal plants used by the Harbang clan of the Tripura tribal community of Mirsharai area, Chittagong district, Bangladesh. J. Altern. Compl. Med. 16(7), 769785.

Rahul, S.Nair., Preeti, Bisht., Sarangi, T.K., 2018. Insights on Cancer Preventive Approaches Using Plant Based Extracts. Asian J Biomed Pharmaceut Sci, 8 (65): 21-27.

Rajan, S., Sethuraman, M., Mukherjee, P.K., 2002. Ethnobiology of the Niligries Hills, India. Phytother. Res. 16(2), 98-116.

Sahid, A., Siahaana, D.P.P.,Rumondora M.J., 2013. Uji Sitotoksisitas Ekstrak Metanol Daun Sisik Naga (Drymoglossum piloselloides Presl.) terhadap Sel Leukemia P388. J. Mipa Unsrat Online. 2(2), 94-99.

Sainani, G.S., Manika, J.S., Sainani, R.G., 1997. Oxidative stress: a key factor in pathogenesis of chronic diseases. Medicine Uptake. 43(1), 167188.
Sandhy, B., Thomas, S., Isabel, W., Shenbagavathai, R., 2006. Ethnomedicinal plants used by the Valaiyan community of Piranmalai hills (Reserved forest), Tamil Nadu, India A pilot study. Afr. J. Tradit. Compl. Alt. Med. 3(1), 101-114.

Siddhuraju, P., Becker, K., 2003. Antioxidant properties of various solvent extracts of total phenolic constituents from three different agroclimatic origins of Drum stick tree (Moringa oleifera Lam.) leaves. J. Agric. Food Chem. 51(8), 2144-2155.

Siddhuraju, P., Becker, K., 2007. The antioxidant and free radical scavenging activities of processed cowpea (Vigna unguiculata (L.) Walp.) seed extracts. Food Chem,101 (1): 10-19.

Sofowara, A., 1993. Medicinal plants and traditional medicine in Africa. Spectrum Books Ltd, Ibadan, Nigeria, 191.

Soltanian, S., Sheikhbahaei, M., Mohamadi, N., 2017. Cytotoxicity evaluation of methanol extracts of some medicinal plants on P19 embryonal carcinoma cells. J. App. Pharm. Sci. 7(7), 142-149.

Somchit, M.N., Hassan, H., Zuraini, A., Chong, L.C., Mohamed, Z., Zakaria, Z.A., 2011.In vitro anti-fungal and anti-bacterial activity of Drymoglossum piloselloides L. Presl. against several fungi responsible for Athlete's foot and common pathogenic bacteria. Afr. J. Microbiol. Res. 5(21), 3537-3541.

Trease, G.E., Evans, W.C., 1989. Pharmacognosy. Bailliere Tindall, London, Ed. 1145.

Wulandari, E.T., Elya, B.,Hanani, E.,Pawitan, J.A., 2013. In vitro antioxidant and cytotoxicity activity of extract and fraction Pyrrosia piloselloides (L.) M.G Price. Int. J. PharmTech. Res. 5(1), 119-125.

Zhao, H., Fan, W., Dong, J., Lu, J., Chen, J., Shan, L., 2008. Evaluation of antioxidant activities and total phenolic contents of typical malting barley varieties. Food Chem. 107 (1), 296-304.

\section{How to cite this article:}

Mini, G., Manju, S., Pratap Chandran, R., 2019. Phytochemical, antibacterial, antioxidant and cytotoxic activities of methanol and aqueous leaf extracts of Pyrrosia heterophylla (L.) M.G. Price. Int. J. Curr. Res. Biosci. Plant Biol. 6(5), 23-38. doi: https://doi.org/10.20546/ijcrbp.2019.605.004 